ヒメミミズ科・コヒメミミズ科の属までの分類

\title{
Classification of the genera that belong to the families Enchytraeidae Vejdovsky, 1879 and Propappidae Coates, 1986 (Annelida: Clitellata: Tubificidae)
}

\author{
鳥居高明* \\ いであ株式会社 環境創造研究所。 テ421-0212 静岡県焼津市利右衛門 1334-5
}

Takaaki TORII*

IDEA Consultants Inc., 1334-5, Riemon, Yaizu-shi, Shizuoka 421-0212, Japan

\begin{abstract}
To date, there is limited information on the taxonomic composition of enchytraeids in Japan. In this study, keys to and diagnoses for the genera of Enchytraeidae and Propappidae have been provided. The keys cover 25 terrestrial, marine, and freshwater genera that have been recorded and are potentially distributed in Japan, and some local or dubious genera were excluded. The major diagnostic characters used in the keys were as follows: 1. shape of the prostomium; 2. presence/ absence and location of dorsal pores; 3. shape and numerical pattern of chaetae; 4. shape and distribution of nephridia; 5 . location of the dorsal blood vessel origin; 6. shape of the chloragocytes; 7. abrupt/gradual transition of the esophagus into the intestine, 8. presence/absence, shape, and position, and size of the esophageal appendages; 9. quantity, size, shape, and texture of the coelomocytes; 10 . shape of the male funnel; 11 . shape of the spermatheca and its attachment (or not) to the esophagus; 12. presence/absence, size, and shape of the testis sacs or seminal vesicles. In addition, the characters of each genus have been described.
\end{abstract}

Key Words: classification, Enchytraeidae, genus, Japan, Propappidae

\section{はじめに}

ヒメミミズ科は，これまでに世界中から 33 属約 700 種 が記録されてきた（Schmelz \& Collado 2012b; Christensen \& Dòzsa-Farkas 2012; Svante et al. 2014)．また, 形態的特徴か らヒメミミズ科に近縁と言われてきたコヒメミミズ科は, これまでに世界中から 3 種が記録され, 日本からも 1 種が 確認された（Torii 2006）。本検索には大きさや形態がよく 似たコヒメミミズ科を含めたが, Erséus et al. (2010) によ ると, 核 DNA およびミトコンドリア DNA の遺伝子解析 の結果から,コヒメミミズ科はヒメミミズ科よりもむしろ ナガミミズ科に近縁であることが指摘されている.

現在までヒメミミズ科全体の分類について網羅的に扱つ た研究としては Nielsen \& Christensen (1959) および Schmelz \& Collado (2010), Schmelz \& Collado (2012a) な どがあるが, これらは主にヨーロッパを中心とした研究で ある. 世界的にみればヒメミミズ科全体の分類学的研究は 未だ不完全であり，記録される種数は今後さらに増加する ことが予想される. 日本におけるヒメミミズ科の分類研究

Received 11 May 2017 Accepted 10 January 2018

* Corresponding author

E-mail: ttakaaki@ideacon.co.jp
は，山口英二博士や中村好男博士らを中心に進められ，こ れまでに 15 属 29 種が記録されてきた。その内，ミジンヒ メミミズ属 Cernosvitoviella Nielsen \& Christensen 1959 とウ ミヒメミミズ属 Stephensoniella Černosvitov, 1934 はそれぞ れ 2011 年, 2013 年と比較的近年に日本から初めて記録さ れた属である（Torii 2011b; 鳥居 2013）。筆者は日本国内で 多くの未記載種と思われる種類を確認しており, 日本にお ける分類学的研究はいまだ不十分な状況といえる. 本検索 表は, 今後の日本に打けるヒメミミズ科研究の一助になれ ばと考え, Nielsen \& Christensen (1959) および Schmelz \& Collado (2010), Schmelz \& Collado（2012a）を参考に, 中 村（1999）や各記載論文の情報, 筆者が新たに日本から確 認した属の知見などを加えて作成した. 小型の貧毛類の観 察に慣れた人であれば，本検索表を参照しながら観察をあ る程度の期間，実際に行うことにより，属までの同定が正 確にできるようになると考えられるが，慣れない間は本検 索表による同定結果と記載論文等との比較・確認が必要で ある。なお，本検索表には世界中から記録されてきた多く の属の中で，筆者が今後日本からも記録される可能性があ ると考えた属について, 陸産, 海産, 淡水産などの生息環 境の区別無く含めたが, 地域固有性が高い属や分類学的に 疑問のある属については筆者の判断で検索に含めなかっ た. 検索中に属和名がついていないものは, これまで日本 からの記録がないことを示す，尚，現在，遺伝子解析を含 
めた系統学的研究が進んでおり, 今後, 属レベルで大きな 変更があることも予想される.

\section{観察に際して}

日本から記録されるヒメミミズ科の多くは，種レベルま で同定されることは極めて少ない。これは，ヒメミミズ科 の分類そのものが発展途上であることや, 分類・同定の為 の日本語の情報が少なく, 分類の鍵となる特徵が分かりづ らかったこと, サイズが数 $\mathrm{mm}$ から数 $\mathrm{cm}$ 程度と小さく, 外見だけでは分類の鍵となる特徵がほとんど無いため, は じめから分類・同定を諦めてしまうこと，種や属の特徴と なる部位の観察が容易でないことなど様々な要因が挙げら れる（鳥居 2012）。しかし, 生きている時は比較的透明で あるため, 水を数滴滴下したスライドグラス上に生きたま まのサンプルを置き, カバーガラスをかけてそのまま生物 顕微鏡を用いて観察することで，特別な処理を施すことな く, 少なくとも属までの同定に必要な多くの内部構造が観 察可能である．ただし，属や種までの同定には成熟したサ ンプルが必要であり, 未成熟のサンプルでは属や種までの 同定は難しい場合が多い. 尚, 生物顕微鏡下で動き回って 観察しづらい場合などは，炭酸水を僅かに滴下すると動き が緩慢になるため見易くなる（Schmelz \& Collado 2010a; 大高私信).

なるべく生きたサンプルを用いて観察することが望まし いが，アルコールやホルマリン，ブアン液等で固定したサ ンプルの場合でも属また種レベルまでの同定は可能である. その場合は, 段階エタノールで完全に脱水後, キシレン $\left(\mathrm{C}_{6} \mathrm{H}_{4}\left(\mathrm{CH}_{3}\right)_{2}\right)$ やサリチル酸メチル $\left(\mathrm{C}_{6} \mathrm{H}_{4}(\mathrm{OH}) \mathrm{COOCH}_{3}\right)$ などで透徹処理を行い，バルサムで封入すれば，内部構造 の観察がある程度可能となる。ただし，分類同定の際に重 要な形質となる唾腺 (peptonephridia) や腎管 (nephridium) は，アルコールやホルマリン固定をすると収縮したり，そ の他の臓器が重なった状態で固定されたりと観察しづらく なる場合が多い，繊細な器官は, 生体の方がよりはっきり と正確な観察が可能であろう.

\section{生態}

ヒメミミズ科は, 氷河やタイガ, 熱帯雨林の土袞中, 河 川底質中, 湿地, 泥炭中, 海浜, 海域の底質中と多様な環 境に生息することが知られている（Nielsen \& Christensen 1959）。その生息環境は, 種や属レベルで異なる場合が多 く, 水分, 温度, 塩分, $\mathrm{DO}, \mathrm{pH}$, 重金属濃度などの環境 条件をよく反映することが知られ（Beylich \& Achazi 1999; Tosza et al. 2010; Römbke et al. 2013), 環境を指標する生物 として重要な分類群と考えられる（鳥居 2012）.

ヒメミミズ科の多くは湿った土㙴中や水際, 水中などの 水分量が豊富な場所から得られることが多い.ただし種に よってはある程度の乾燥耐性を持つことがわかっており, 八タケヒメミミズ属 Fridericia の仲間では, 表皮構造の一
部であるクチクラ層を肥厚させることでほかのヒメミミズ 科と比較して乾燥耐性を高め, 比較的乾燥した土袞中にも 生息することができる（Schmelz 2003）。食性は，多くの 場合は土㙴中の有機物や微生物を砂泥と一緒に飲み込んで 消化吸収しているものと考えられる。特殊な環境に適応し ている例として, コオリミミズやアイスワームなどの名前 で知られている Mesenchytraeus solifugus Emery, 1898 は, 北アメリカの水河や雪溪に生息するナカヒメミミズ属の一 種で，低温環境に適応したATP 合成機能を有しており， 全生活史を $0^{\circ} \mathrm{C}$ 以下の低温環境で完結できる唯一の貧毛類 として知られる (Dial et al. 2012). 本種は氷河や雪溪の表 面に生える藻類を食べて生活することが知られている (Murakami et al. 2015). Aspidodorilus や Pelmatodrilus の仲 間は大型の陸棲貧毛類に外部片利共生することが知られて いる(Moore 1943). ホソヒメミミズ属（和名新詳） Grania の仲間の一部は水深 1000-3000 m 程度の深海に生 息する種が知られ，これらの種では頭部先端に感覚器と考 えられる乳頭状突起を持つことが知られている（Rota \& Erséus 2003).アミメヒメミミズ属 Chamaedrilus の仲間は $\mathrm{pH} 4.5$ から 5.0 程度の酸性土㙴中で個体数密度が高くなる ことが知られている (Römbke et al. 2013). タケヒメミミ ズ属 Bryodrilus やハンヒメミミズ属 Hemienchytraeus, ミ ジンヒメミミズ属 Cernosvitoviella の仲間は湿った土壤中 に生息するが，一部の種はファイトテルマータ等の植物が 保持する小水界にも生息することが知られている（Schmelz et al. 2015).

その他, 特徵的な種として, ヒメミミズ属 Enchytrareus の仲間の一部（ヤマトヒメミミズ E. japonensis, E. bigeminus, E. dudich など）は, 有性生殖以外に自切による無性生 殖による増殖を行う。十分に成長した個体が数体節ずつの 長さの断片へと自切・分離した後, それぞれの断片が頭部 と尾部を再生し完全な個体へと再生することが知られてい る (Myohara et al. 1999; Collado et al. 2012).

\section{体の基本構造}

外部形態 (Fig. 1, 2)：ヒメミミズ科の体の大きさは, 体 長がおよそ $2 \mathrm{~mm}$ から $30 \mathrm{~mm}$ 程度, 体幅がおよそ $0.1 \mathrm{~mm}$ から $1.0 \mathrm{~mm}$ 程度と全体的に小型である。体色は属や種に よってある程度異なっているが, 胃内容物や血液などによ り同じ種や属でも異なる色に見えることもある．基本的に は白色を基本とした薄いピンク色や肌色をしているが，ケ ナシヒメミミズ属Achaetaの一種は薄い緑色を呈す種が存 在する他, ミズヒメミミズ属 Marionina の一種では体腔細 胞が光を反射するなどの理由により実体顕微鏡下でみると 白い斑模様がみえる場合もある。他のミミズ類と同様に体 表面に目立った構造は無いが, コヒメミミズ科では口前葉 と呼ばれる細長い突起が頭部先端に付くことがある。基本 的な体の構造としては, 細長い単純な体型であり, その他 のミミズ類と同様に体節構造を持つ. 眼点は無く, 通常各 
体節に先端が単純な剛毛を持つ（コヒメミミズ科では先端 が二叉した剛毛を持つ）が（Fig. 3,4）, ケナシヒメミミズ 属やミズヒメミミズ属の一部の種では剛毛を全く持たない 場合もある，各体節には普通は体側（背側）に 1 対, 腹側

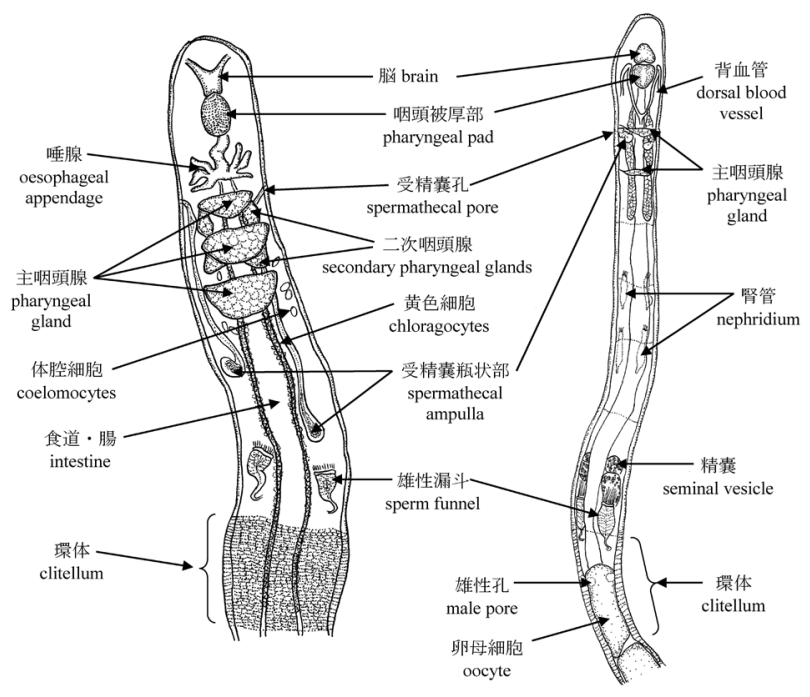

Fig. 1. Overview of enchytraeid anatomy and anterior segments. Left dorsal view of Hemienchytraeus sp. and right lateral view of Marionina sp., with some organs omitted.
に 1 対の剛毛束を持つ. 剛毛は体壁からある程度の出し入 れが可能で, 剛毛を基質に引っかけることにより蠕動運動 による進退を容易にしている，成熟した個体では第 12 , 13 体節および周辺などが肥厚することで環帯を形成し, 雄性生殖孔が第 12 体節の腹側部に開く。環帯は主に顆粒 細胞と硝子体細胞の 2 種類から成り，それら細胞の分布パ ターンはしばしば属や種の特徴の一つとなる。ヒメミミズ

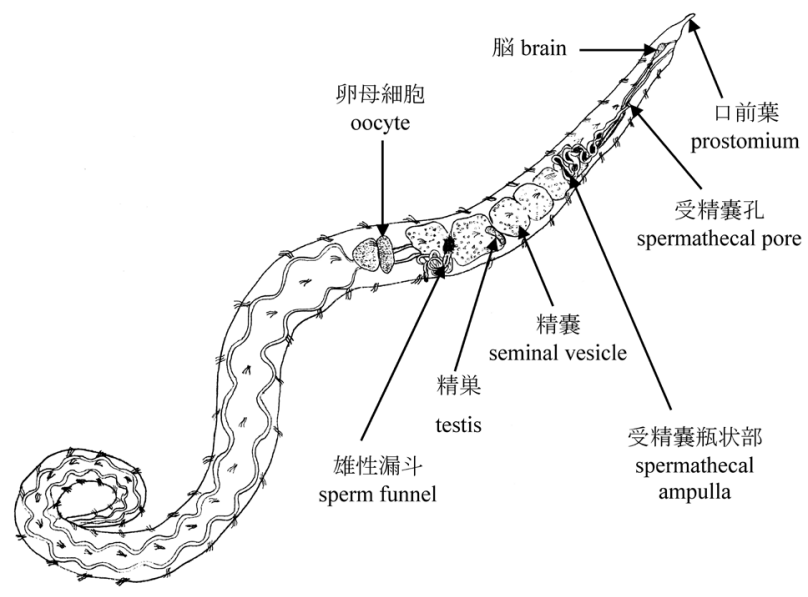

Fig. 2. Overview of propappid anatomy. Lateral view of Propappus volki, with some organs omitted.

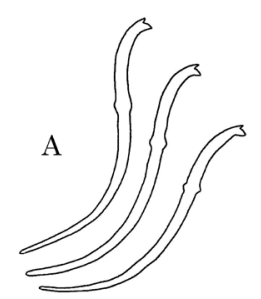

Propappus

$\mathrm{S}$ 字状，先端 2 叉，結節あり． chaetae sigmoid, with bifid distal ends, with nodulus
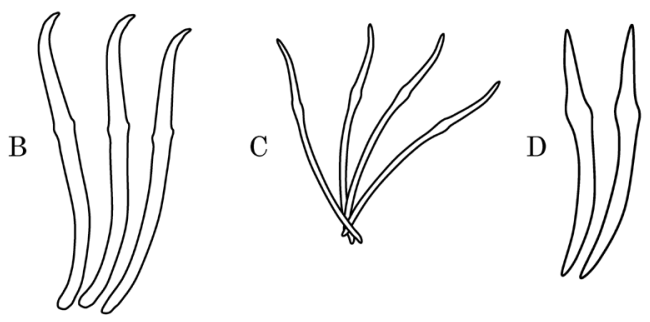

Mesenchytraeus
Stercutus

\footnotetext{
$\mathrm{S}$ 字状, 先端単純, 結節あり (明瞭でない場合もある) chaetae sigmoid, distal ends simple, with nodulus
}

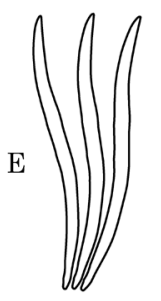

Chamaedrilus

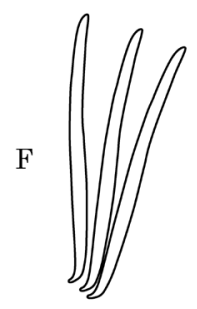

Lumbricillus(一部)

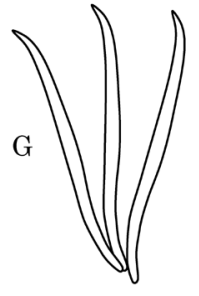

Marionina(一部)

先端単純, $\mathrm{S}$ 字状, 結節なし

chaetae sigmoid, distal ends simple, without nodulus

Fig. 3. Variations in the shape of chaetae in enchytraeids. 


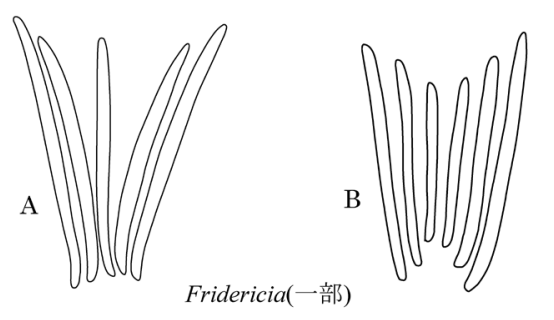

先端単純，剛毛は真つ直ぐか多少曲がり、基部は曲がる

chaetae straight or slightly sigmoid, with ental hook, distal ends simple, without nodulus

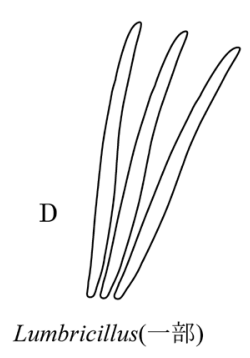

先端単純, 真つ直ぐか多少曲がる

chaetae straight or slightly sigmoid, without ental hook, distal ends simple, without nodulus
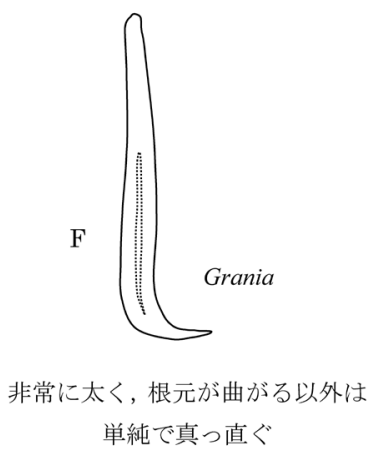

chaetae straight and stout, with ental hook, distal ends simple, without nodulus

Fig. 4. Variations in the shape of chaetae in enchytraeids (continued).
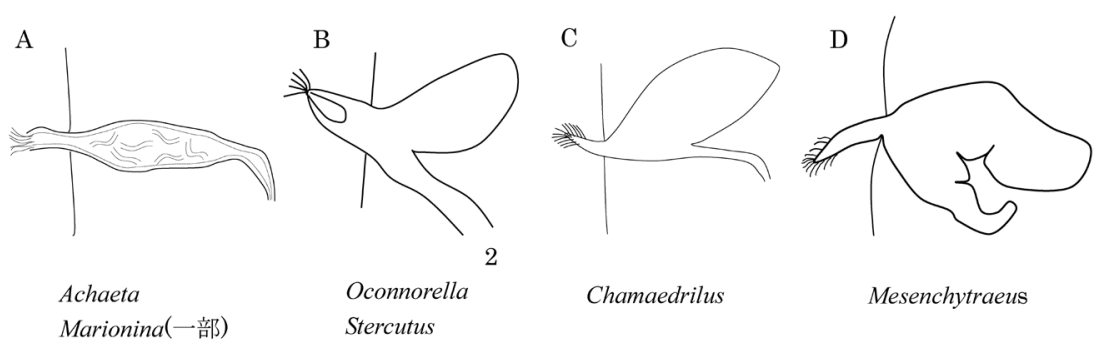

Stercutus

Globlidrilus

Fig. 5. Variations in the shape of nephridia in enchytraeids.

科は，受精囊孔は第 4 体節と第 5 体節の間の体側部に開く （ただし雄性生殖孔や受精囊孔は非常に小さいため, 外部 から認めることは難しいことが多い）が，コヒメミミズ科 では第 3 体節と第 4 体節の間の体側部に開く.

内部形態 (Fig. 1, 5, 6, 7,8)：ヒメミミズ科を属や種まで 同定するためには, 必ず内部構造を観察する必要がある. 基本的に, 大型ミミズ類と同様に脳や食道, 血管系, 神経 系, 腎管, 体節構造, 生殖器官などを持つことに変わりは 無いが, それらの形態や位置が分類する際の重要な特徵と なる. 特に腎管や雄性生殖器官 (雄性生殖孔の形態や輸精 管の太さや長さなど), 受精器官（受精囊瓶状部の形態や 受精囊導管・排出管の形態, 長さなど) は, 剛毛の形態や 数と並んで分類の重要な鍵となる. また, 一部の属では唾
腺（食道付属器の一種）や食道付属器（唾腺以外の食道付 属器）と呼ばれる器官が存在し, その存在の有無や形態も 属を区別する重要な特徵である. 分類の重要な鍵として は, 前述した器官以外にも体腔に存在する体腔細胞や背血 管の始まる位置, 食道や腸の接続部の状態, 咽頭腺, 中枢 神経の形態といった様々な器官を詳細に観察する必要が生 じる. 各属に共通する構造として, 頭部背面にはほとんど の場合頭孔があり, 口前葉と囲口節との間もしくは口前葉 先端に存在する. 多くの場合, 各体節の表皮上に腺細胞 （表皮腺細胞）が存在し, 環帯前方の方が後方よりも数多 く存在するが，はっきりと見えない場合も多い，成熟する と, 第 12 と 13 体節の表皮に卵塊を形成するための分泌細 胞が形成され, 表皮が分厚くなり, それが環帯となる. 中 
A

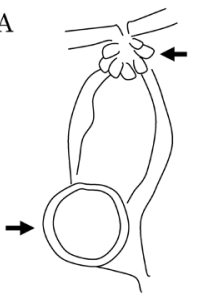

受精囊瓶状部に憩室あり
受精襄孔に腺組織あり
spermathecal ampulla
with diverticula,
spermathecal pore with
glandular tissue
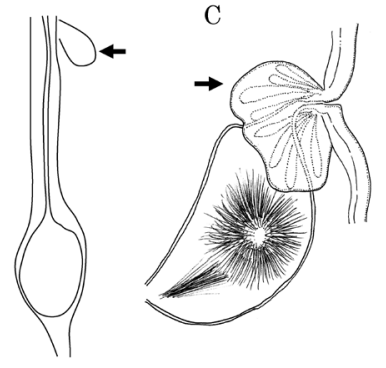

受精囊瓶状部に敗室なし
受精囊孔に腺組織あり
spermathecal ampulla
without diverticula,
spermathecal pore with
glandular tissue

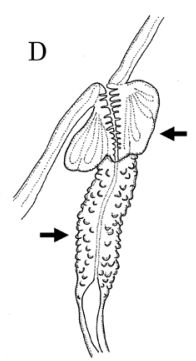

受精囊瓶状部に㮃室なし 受精囊孔および受精囊瓶状部 の導管に腺組織あり spermathecal ampulla without diverticula, spermathecal pore and ectal duct with glandular tissue

Fig. 6. Variations in the shape of the spermatheca in enchytraeids.

枢神経組織は体腔の中央に位置し，隔膜を貫いて存在す る. 脳は比較的細長く，第 1,2 体節上に存在する. 第 3 体 節上では食道の上皮組織が発達し, 咽頭被厚部が形成され る. 通常，第 4，5，6体節にそれぞれ 1 対ずつ，合計 3 対 の比較的大きな腺組織が存在し，それらは咽頭腺，もしく は食道腺と呼ばれ, 前方は咽頭に接続し, 後方は隔膜に接 続する，咽頭腺はホルマリン等で固定しても透過光ではそ の部分が暗く見えることから，ヒメミミズ科とその他の科 とを区別する際にわかりやすい特徴となる，食道と腸は はっきりとは分けられないことが多いが，食道と腸の繋ぎ 目で急激に拡張する属ではわかりやすい.

\section{ヒメミミズ科・コヒメミミズ科 属までの検索}

検索中の*は和名新称，太字は日本から記録がある属である. 1a. 全ての剛毛の先端は 2 叉. 口前葉が長く伸びる場合が ある. 受精囊孔は第 4 体節（第 3 体節と第 4 体節の間） に位置する (Fig. 2).

…コヒメミミズ科（コヒメミミズ属 Propappus）

1b. 全ての剛毛の先端が単叉または一部の剛毛が 2 叉, もしくは全く剛毛を持たない，受精囊孔は第 5 体節（第 4 体節と第 5 体節の間）に位置する（Fig. 1).

ヒメミミズ科 2

2a. 第 2 体節と第 3 体節の腹側のみに 2 叉型剛毛を持つ.

Barbidrilus 日本未記録

2b. 全ての剛毛の先端は単純であるか全く剛毛を持たな い.

3a. 剛毛を全く持たない. 主に陸域に生息. 卵型や洋ナシ 型の透明な梨状腺が本来の剛毛の位置に存在する場合が ある（水際などの湿潤環境からは，剛毛を全く持たない ミズヒメミミズ属 Marioninaの一種が報告されている.

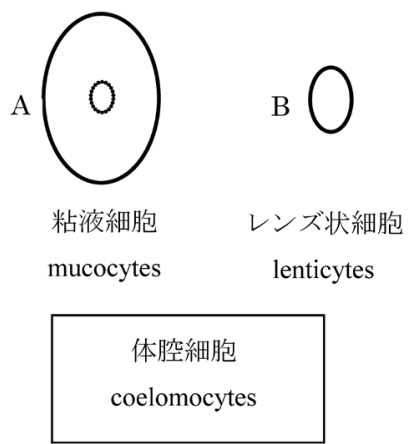

Fig. 7. Two types of coelomocytes in the enchytraeids. Left, nucleate mucocyte; right, lenticyte.

両属の区別点は, 透明な梨状腺の有無, 生息環境, 受精 囊，腎管の形状などの組み合わせから判断する必要があ る). ケナシヒメミミズ属 Achaeta

3b. 剛毛を持ち, 全ての剛毛の先端は単叉である（Fig. $3 \mathrm{~B}-\mathrm{G}, 4 \mathrm{~A}-\mathrm{F})$. 4

4a. 剛毛は $\mathrm{S}$ 字状で中央付近に結節（膨らみ）がある. 結節の膨らみは僅かである場合がほとんどであるため見 慣れないと判別しづらい（Fig. 3A-D). 腹側前方の剛毛 束は 3 本以上から構成される。 5

4b. 剛毛には結節がない（ミュキヒメミミズ属 Stercutus では中央がやや瘤状に隆起する程度）(Fig. 3E-G, 4AF).

5a. 腎管は隔膜後方で分葉する＝腎管後端はやや切れ达む 形で分葉する (Fig. 5D). 中型から大型の種が多い.

\section{ナカヒメミミズ属 Mesenchytraeus}

5b. 腎管は隔膜後方で分葉しない (Fig. $5 \mathrm{~A}-\mathrm{C})$.………6

6a. 主に河川や湿地, 池沼の水際など, 湿潤な場所に生 息. 体長 3〜8 mm 程度と小さな種がほとんど．腎管は 隔膜後方で分葉せず，腎管の排出管は末端につく（Fig. $5 \mathrm{~A})$. ミジンヒメミミズ属 
A
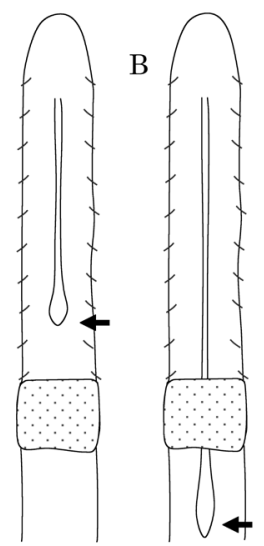

背血管が始まる位置

dorsal blood vessel

origin in a post or pre

clitellar segment
C

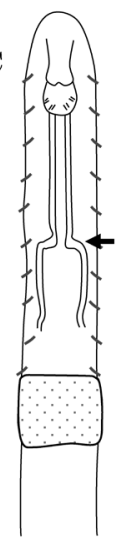

突然

sudden
D

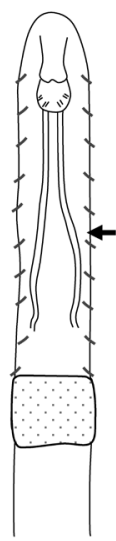

なだらか

smooth

食道之腸の接続

gut dilatation
E

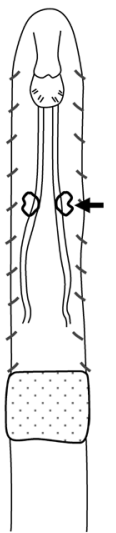

食道憩室あり

with oesophageal

appendages

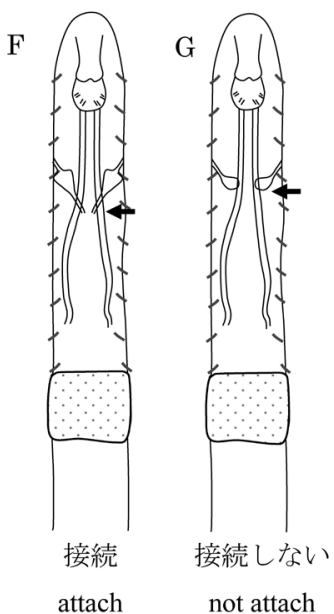

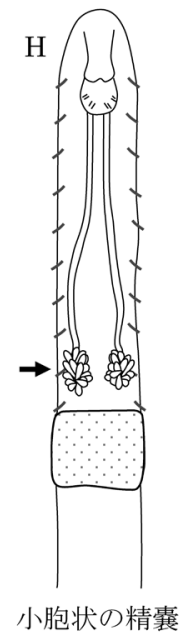

testis sacs like bouquet of vesicle-shaped lobes

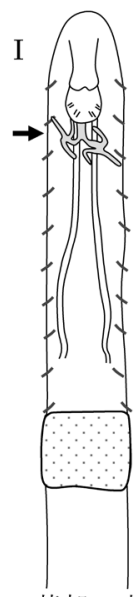

基部 1 本

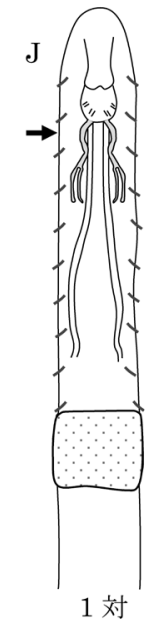

1 対

受精襄と食道 spermathecae

attach or not

attach to

oesophagus

not divided from divided from

the base the base

唾腺あり

with oesophageal

appendage

Fig. 8. Overview of enchytraeid anatomy, extract several features.

6b. 上記の特徵は当てはまらない。前方の腹側剛毛はそ れ以外の剛毛の 2 倍程度の太さになることがある. 背血 管は環帯よりも前から始まる (Fig. 8A). 雄性漏斗は小 さい，受精囊瓶状部は単純で惒室はなく，食道に繋がら ない. 黄色細胞はとても大きく, 時に体腔が黄色細胞で 充満する。

$$
\text { ミユキヒメミミズ属 Stercutus }
$$

7a. 剛毛は $\mathrm{S}$ 字状に曲がり結節を持たない（Fig. 3E-G）.

7b. 剛毛は単純で基部が傘の柄状に曲がる以外は真っ直 ぐか多少カーブする (Fig. 4).

8a. 背血管は環体より前から始まる (Fig. 8A). 8b. 背血管は環体より後ろか，環体の中から始まる（Fig. $8 \mathrm{~B})$. 10

9a. 食道は徐々に腸と癒合していく（Fig. 8D). 食道㕷室 はない，受精囊は食道や腸と繋がらず自由に存在する. 黄色細胞はとても大きく, 時に体腔が黄色細胞で埋ま る.酸性ではない森林土壌にみられる.

\section{ミユキヒメミミズ属Ｓtercutus}

9b. 食道と腸の接合部は第 7 体節か第 8 体節で突然繋か る（Fig. 8C). 食道毠室は第 4 体節と第 7 体節と第 8 体 節の間に 1 対ずつ，合計 2 対ある．受精囊は食道に繋が る (Fig. 8F). 
10a. 食道輴室が第 6 体節に 2 対ある. 受精囊は細い排出 管によって食道背面につながる（Fig. 8F）。粘液細胞 （Fig. 7A）は円盤状か多少楕円形となる.

タケヒメミミズ属 Bryodrilus

10b. 食道頽室は存在しない. 受精囊はどこにもつながら ず自由に存在するか，部分的に食道とつながっている. 粘液細胞は円盤状ではない。

. 11

11a. 受精囊はどこにもつながらず自由に存在する（Fig. $8 \mathrm{G})$.

11b. 受精囊は食道に繋がる（Fig. 8F）。 $\cdot 13$

12a. 第 2 体節と第 3 体節の間に腎管がない，腎管の末端 部に小胞状の頽室を持たない。背孔，食道憩室は無く， 食道と腸は徐々につながる（Fig. 8D）. 高層湿原のミズ ゴケ堆積土壤などの酸性土袞に多い。

\section{アミメヒメミミズ属 Chamaedrilus}

12b. 第 2 体節と第 3 体節の間に腎管がある。背孔，食道 䄸室は無く, 食道と腸は徐々につながる（Fig. 8D)。腎 管の末端部に小胞状の憩室を持つ.

Euenchytraeus 日本未記録

13a. 精囊は発達し, 細かく分割された状態 (小胞状) と なることが多い（Fig. 8H）。腎管の中央か末端から排出 管が出る (Fig. 5A, B). 受精囊孔周辺には腺細胞が付随 する (Fig. 6A-D). 生殖器官は通常の位置にある。一般 的に薄赤色から薄緑色を呈しており, 海水から淡水まで 幅広く生息している。

…….......ツリヒメミミズ属（一部） Lumbricillus

13b. 精囊は小さく，細かく分割された状態とはならない か，ほとんど存在しない．腎管の排出管は腎管の末端付 近から出る (Fig. 5A). 背血管は脳神経節の後方で分岐 する. 生殖器官は通常の位置にある. 受精囊瓶状部の壁 は薄く，内部の精子は束，または塊状となる。受精囊は 基本的には食道に接続するが見えにくく，内管は食道と 繋がらない.............タマヒメミミズ属 * Globulidrilus

14a. 剛毛はとても太く, 根元が曲がる（ブーツ状）以外 は単純で真っ直ぐ．剛毛の根元は直角に近い角度かまた は鉤状に曲がる（長靴の様な形に見えることもある）。 主に汽水から海水に生息する。

14b. 剛毛は上記（Fig. 4F）ほど太く大きくはない, …15

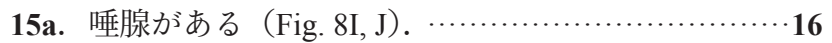

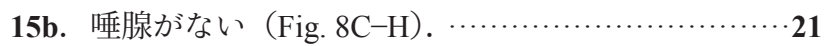

16a. 唾腺が 1 本あり, 後端が 2 つに分かれる（Fig. 8I). 腎管の隔膜前方部は腎管本体の一部が含まれる.

….............ハンヒミミズ属 Hemienchytraeus

16b. 唾腺は対となる（基部から分かれる）(Fig. 8J)。‥17

17a. 背孔はあり, 第 7 体節から始まる. 背血管は環帯後 方から始まる (第 14-25 体節)。剛毛は 1 束に 2-16 本あ り, 真ん中に位置する剛毛が最も短い. 粘液細胞とレン ズ状細胞が存在する．体長は 4 25 mm 程度である. 17b. 背孔はない.

\section{8}

18a. 粘液細胞とレンズ状細胞が存在する。背孔がないと いう特徵以外はハタケヒメミミズ属と同様の特徵をも つ. …….........................Timmodrilus 日本未記録

18b. 粘液細胞のみが存在し，レンズ状細胞はない. $\cdots \cdots 19$

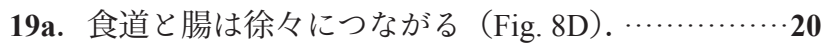

19b. 食道と腸は第 7 体節と第 8 体節の間辺りで突然つな がる（Fig. 8C）. 腸の付属器は第 7 体節の背側面にある. 背血管は第 7 体節から始まる（Fig. 8A）。腎管は第 4 体 節と第 5 体節の間から始まる。……Enchylea 日本未記録 20a. 背血管は第 12-18 体節から始まる（Fig. 8B）. 剛毛束 の中の剛毛は全て同じ長さ。背孔はない.

\section{ヒメミミズ属 Enchytraeus}

20b. 背血管は環帯間か環帯後方から始まる（Fig. 8B）. 剛毛束の中の剛毛は中よりほど小さい。背孔はない。腎 管の隔膜前部分は漏斗部のみから成る.

Oconnorella 日本未記録

21a. 食道と腸は突然つながる（Fig. 8C）。しばしばそのつ ながる場所に腸の付属器が存在する。…..............22

21b. 食道と腸は徐々につながる（Fig. 8D）。腸に付属器 は存在しない. $\cdots \cdots \cdots \cdots \cdots \cdots \cdots \cdots \cdots \cdots \cdots \cdots \cdots \cdots \cdots \cdots \cdots \cdots \cdots \cdots \cdots \cdots \cdots \cdots$

22a. 背血管は環帯の前方から始まる（第 8-9 体節）(Fig. 8A). またその基部付近には 2, 3 節の拍動する心臓の ような膨らみがある。第 8 体節に 0,2 もしくは 4 つの 食道憩室がある. 1 体節に 2 本以上の剛毛を持つ. 剛毛 は直線状でほぼ長さが等しい。剛毛束の真ん中のものが 最も短いが対になるわけではない.

\section{コブヒメミミズ属 Henlea}

22b. 背血管は環帯の前方か, 環帯の中から始まる。 $\cdots \cdot 23$

23a. 背血管は第 10-12 体節から始まる。一束に 2 本の剛 毛を持ち, 第 4 体節の食道背側に小さな付属器を持つこ とがある。また，食道と腸のつなぎ目の部分に大きな 1 対の付属器を持つことがある.

23b. 背血管は第 13 体節から始まる。心臓のような膨ら みは無い．第 6 体節の腸の側方に付属器が 2 つあ。. 各 体節に 2 本の剛毛を持つ. 第 8-11 体節の側部には剛毛 束を欠く.…………………Enchytronia 日本未記録

24a. 第 8 体節以降に背側剛毛を持つ. 腎管の隔膜前方部 は腎管本体の一部が含まれる。大きな空隙状の食道憩室 が第 7 体節と第 8 体節にある。

Guaranidrilus 日本未記録

24b. 第 8 体節以降に背側剛毛を持たない. Xetadrilus 日本未記録

25a. 粘液細胞に加え，レンズ状細胞も存在する．体長は 2〜3 mm 程度である. ............Hemifridericia 日本未記録

25b. 粘液細胞のみがある。 $\cdots \cdots \cdots \cdots \cdots \cdots \cdots \cdots \cdots \cdots \cdots \cdots \cdots \cdots \cdots \cdots \cdots \cdots \cdots$

26a. 精囊は発達し, 細かく分割された状態（小胞状）と なることが多い（Fig. 8H），受精囊には憩室がなく，食 道と繫がる（Fig. 6C, D)。隔膜前の腎管は漏斗状の部分 
だけからなる。腎管の排出管は腎管後端から出る（Fig. $5 \mathrm{~A})$ ，血液は普通赤色である。

………...リヒメミミズ属（一部） Lumbricillus

26b. 精巣は全く無いか, ある場合は細かく分割された状

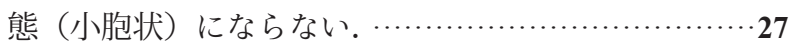

27a. 受精囊に球形（又は楕円形）の㮩室がある（Fig. $6 \mathrm{~A})$. 剛毛束は 2,3 本から成る.

ウミヒメミミズ属 Stephensoniella

27b. 受精囊には㮩室がなく, 食道と繋がる。………28

28a. 腎管の隔膜前部分は漏斗部のみから成る.

…………………….... Oconnorella 日本未記録

28b. 腎管の隔膜前部分には本体部を伴う。腎管の排出管 は体節中央から後方付近から出る. 受精囊には頽室がな

く，食道と繫がる。

…29

29a. 受精囊瓶状部は比較的大きく, 壁は薄い. 受精囊は 食道と接続するが見えにくく，内管は繋がっていない， 多くの場合, 瓶状部内部の開口部基部には精子束が存在 する。

タマヒメミミズ属 * Globlidrilus

29b. 上記の特徵を満たさない.

ミズヒメミミズ属 Marionina

30a. 受精囊孔内側周辺に腺組織が付属する. 1 剛毛束 1 本であることが多い.................Randidrilus 日本未記録

30b. 受精囊孔内側周辺に腺組織が付属しない. ……....31

31a. 1 つの剛毛束は 1 本から成ることが多い. 剛毛は太 長く, 多くの場合, 長さは少なくとも体幅の $1 / 2$ 以上 (Fig. 4F). 受精囊瓶状部に礊室はない.

ホソヒメミミズ属 * Grania

31b. 剛毛束は 2,3 本から成る. 剛毛は上記ほど太くな く, 剛毛の長さは体幅の $1 / 2$ 以下の長さ。受精囊瓶状部 に球形（又は楕円形）の憩室がある（Fig. 6A）。

ウミヒメミミズ属 Stephensoniella

\section{各属の概説}

コヒメミミズ科 Propappidae Coates, 1986

コヒメミミズ属 Propappus Michaelsen, 1905

コヒメミミズ科は Propappus の 1 属から成る科である. 旧北区から 3 種が知られ, 日本からはナガ八ナコヒメミミ ズ (Propappus volki Michaelsen) 1 種が本州から記録され ている（Torii 2006）。体長は 5-7 mm 程度. 外見はヒメミ ミズ科に似るが, 長い口前葉を持つ点や, 全ての剛毛が 2 叉する点, 受精囊孔の位置がヒメミミズ科では第 5 体節 （4/5）にあるのに対し, 本科では第 4 体節（3/4）に位置 する点などで容易に区別できる，主に比較的清澄な河川の 中上流の砂礫底から見いだされ，時には優占種となるほど 多くみられる。旧北区に広く分布し, 表層水域から地下水 域まで広く利用していると考えられている. 日本でも伏流 水を含む地下水域も生息環境として利用しているとみられ （Torii 2006）, 河川下流域でも伏流水が湧出するような場
所から多産することがある. 少なくとも本州中部から九州 には分布している (鳥居未発表).

ヒメミミズ科 Enchytraeidae Vejdovsky, 1879

ケナシヒメミミズ属 Achaeta Vejdovsky, 1877

全く剛毛を欠き，1-3 対の表皮腺を各体節に持つ. 表皮 腺を全く久く種も存在する. 受精囊（spermatheca）は第 5 体節から第 10 体節まで伸張することもあり, 受精囊瓶状 部は明確な区切りが無く受精囊孔から徐々に瓶状部とな る. 脳神経節は後方に凸型となる。精囊は小さく, 雄性孔 の周囲にはいくつかの小さな腺組織がみられる. 小さな食 道㮩室が第 4 体節もしくは第 5 体節にある場合がある. 頭 部背面の孔は口前葉の近くに開く（Nielsen \& Christensen 1959). ホソヒメミミズ属 Grania やミズヒメミミズ属 Marioninaにも剛毛を全く欠く種が居るが, 梨状腺がない ことや受精囊の形態, 生息場所（ホソヒメミミズ属は海〜 汽水域, ミズヒメミミズ属は主に淡水〜海域の水辺などの 湿潤環境，ケナシヒメミミズ属は主に陸域）などにより区 別できる. 日本からはフツウケナシヒメミミズ A. camerani (Cognetti) のみが知られ, 北海道, 本州から記録されてい る（中村 1999）が, 本種以外の種も確認している（鳥居 未発表).

属和名無し Aspidodorilus Baylis, 1914 検索表に含めず 剛毛は直線的で結節はなく, 体後方にいくほど数が増え る (14-20 本). 体の前方は円筒形で後方は背側と腹側が平 らになる.頭孔と背孔はない，食道と腸は突然繋がる．背 血管は第 8 体節から始まる. 第 7 体節に食道憩室がある。 陰茎球は小さい, 受精囊は単純で, 受精囊孔周辺に筋肉組 織が発達し, 食道に繋がらない. 大型の陸棲貧毛類の体表 面に寄生し, 体表面の分泌物に付着する土壌粒子やバクテ リア，有機物等を摂食すると考えられる（Coates 1990）. 西アフリカから記録され, 日本から本属の記録はない。

タケヒメミミズ属 Bryodrilus Ude, 1892

結節が無く, 若干カーブするか $\mathrm{S}$ 字状の剛毛を持ち, 長さが異なる剛毛で 1 束が構成されている. 第 6 体節の食 道に 4 つの食道㕰室がある. 背血管は環体の中か, 環体の 後から始まる。体腔細胞は一定の形と大きさで揃ってい る. 隔膜前の腎管は漏斗部のみであり, 排出管は腎管の前 方にあたる隔膜近くか, 腎管の中程の部分から始まる. 単 純な受精囊があり, 普通は食道の背面側に繋がる. この属 は第 6 体節の食道に付属器が 2 対あることで他のヒメミミ ズ科から区別できる（Zhicai 2000）。日本からは北海道の 森林土壌から本属の 1 種（種は未確定）が記録されている (Nakamura \& Christensen 1978).

ツイコブヒメミミズ属Ｂuchholzia Michaelsen, 1887 この属は以下に挙げるいくつかの特徴の組み合わせによ 
り他の属から区別出来る.

$\mathrm{S}$ 字状剛毛を持ち，体の中程にいくにつれて剛毛のサイ ズが小さくなる. 小さな食道秝室が第 4 体節にある. 背血 管は環体の前からはじまる，食道から腸へ移行する間（第 7 体節と第 8 体節の間）の背側に 1 つか 2 つの㕰室がある (Healy 1996). 日本からは北海道の森林土壌から本属の 1 種（種は未確定）が記録されている（Nakamura \& Christensen 1978).

ミジンヒメミミズ属 Cernosvitoviella Nielsen \& Christensen 1959

Mesenchytraeus と同様に, S 字状で結節がある剛毛を持 つが, 体長が 2-5 mm 程度と小さい種が多い (Mesenchytraeus は $10 \mathrm{~mm}$ 以上の種が多い). 脳神経節の後方は中央で切 れ込む. また, 生息場所についても Mesenchytraeus と同様 に湿潤な場所（川岸や湿地, 海岸など）であることが多い. 食道と腸は徐々に慗がる. 背血管は環帯の中か後方より始 まる. 2, 3 対の主咽頭腺と 2 次咽頭腺を持つ. 輸精管は短 く, 雄性漏斗付近で太くなる. 雄性孔周辺には小さな腺組 織が付属する。受精囊は単純な構造で食道に繋がらない. 元々はMarioninaに含められていたが，剛毛に結節を持つ こと，輸精管の漏斗側が膨らむこと．真の陰茎球を持たな いこと，雄性孔に腺組織が付属することなどにより区別さ れた (Nielsen \& Christensen 1959). 近年, 静岡県の山間湿 地や渓流脇などの湿潤環境からミジンヒメミミズ C. minor Nielsen \& Christensen 1959 が記録された（鳥居 2011b）が日 本にはその他複数種が存在する (鳥居未発表).

\section{アミメヒメミミズ属 Chamaedrilus Friend, 1913}

これまで Cognettia Nielsen \& Christensen, 1959 に含まれ ていた種は, 本属および Euenchytraeus Bretscher, 1906 のシ ノニムとされた（Martinsson et al. 2014）。本属は，第 2 体 節と第 3 体節の間に腎管を持たない点および腎管の未端部 に小胞状の咊室を持たないことでEuenchytraeus から区別 できる. 結節のない $\mathrm{S}$ 字状の剛毛が 1 束に 2 ～ 3 本ある. 腎管の隔壁前は漏斗部だけで成り立ち，排出管は腎管部の 前〜中ほどから出る．食道や腸に䄭室はない，背血管は環 体の中か, 環体の後から始まる. 単純な陰茥球と単純な受 精囊を持ち, 食道には繋がらない, 精巣, 卵巣, 雄性孔は 最大 4 体節分前方に置き換わることがある (Healy 1996). 日本からは岩手県からハヤチネアミメヒメミミズ C. hayachinensis（Nakamura）の記録があるほか, 北海道の森林土 壌から本属の 1 種（種は未確定）が記録されている（Nakamura \& Christensen 1978). 最近, Torii（2015）によりオゼ アミメヒメミミズ C. ozensis が尾瀬ヶ原から記載された. 高層湿原のミズゴケ湿地などの酸性土壌に多い.

属和名無し Enchylea Nielsen \& Christensen 1963

日本から本属の記録はない。唾腺を持ち, その形態は
Enchytraeus albidus group にとてもよく似ている. Enchytraeus albidus group よりも体サイズが小さい点や Enchylea は食道㮩室があるがEnchytraeus では食道憩室がないなど の特徴により区別される。これまで研究用農地からのみ確 認されていたが，2010年に自然環境としては初めてポル トガルの耕作地から確認された（Schmelz \& Collado 2013）.

\section{ヒメミミズ属Ｅnchytraeus Henle, 1837}

土壤性種, 淡水産種, 海産種を含む属であり, 小さな精 巣と小さな精囊をもつ. 1 対の枝分かれしない唾腺をも つ. まっすぐで, 結節のない剛毛をもつ. 生時は通常黄色 から白色を呈す，雄性孔に大きな陰茎球を持つ種と小さな 陰茎球をもつ種が存在し，それらは亜属レベルで分かれる と考えられる。受精囊孔には腺組織が付随する。脳神経節 の後方は凹まず平らか凸型（突出）となる（Coates \& Ellis 1981). 日本からは，シロヒメミミズ Enchytraeus albidus Henle, ミサカヒメミミズ Enchytraeus buccholzi Vejdovsky, ヤブヒメミミズ Enchytraeus minimus Bretcher, ヤマトヒメ ミミズ Enchytraeus japonensis Nakamura の 4 種が知られる が, ヤブヒメミミズはミサカヒメミミズのシノニムとされ る（Kasprzak 1986）ため, 日本産 3 種. シロヒメミミズ は河川下流域の水際（鳥居未発表）や堆肥中（中村 1999） から見出される。なお，ミサカヒメミミズは世界中から確 認されているが, 遺伝子解析の結果から, かなり多くの隠 蔽種を含んでいるようである (Erséus 私信).

属和名無し Euenchytraeus Bretscher, 1906

日本から本属の記録はない。これまで Cognettia Nielsen \& Christensen, 1959 に含まれていたいくつかの種は, 本属 のシノニムとされた（Svante et al. 2014）. Chamaedrilusに 似るが，本属は第 2 体節と第 3 体節の間に腎管を持つ点お よび腎管の末端部に小胞状の憩室を持つことでChamaedrilus と区別できる.

ハタケヒメミミズ属 Fridericia Michaelsen, 1889

基本的には背孔が有ることによって他属と区別できる. 形態的にはIsosetosa や Timmodorilus によく似た属であり, Fridericia は背孔を持つ点で両属から区別される。しかし 現在, Isosetosaについては nomen dubium（疑問名）とし て扱われ, TimmodorilusについてはFridericia との区別点 は背孔の有無のみである. 2000 年には中国から背孔がか なり小さく，第 7 体節まで無く，第 8 体節から始まる種 (Fridericia paraunisetosa) が報告されていることから，進 化の過程で背孔が減少した可能性が示唆されている. Fridericia 以外に背孔をもつ種としては, 唯一 Enchytraeus humicultor が報告されているが，本種については背孔以外 の特徴は全て Enchytraeus albidus と一致することから, 研 究者によってはシノニムとして扱うこともあり, 背孔の有 無についての真偽は不明である. Enchytraeus, Fridericia 
両属ともに 1 対の唾腺をもつ（Schmelz 2003）。 日本から は次の 5 種が知られる. ブルボイデヒメミミズ Fridericia bulboides Nielsen et Christensen, ムギハタケヒメミミズ Fridericia bulbosa (Rosa), フクシハタケヒメミミズ Fridericia fuchsi Eisen, ハタケヒメミミズ Fridericia perrieri (Vejdovsky), ラッツヒメミミミズ Fridericia ratzeli (Eisen). 本属は, 本州では森林から平地の土壤中, 畑や 草地, 渓流の水際等, 様々な環境から頻繁に確認される.

タマヒメミミズ属（和名新称） Globulidrilus Christensen \& Dòzsa-Farkas, 2012

主に淡水域から汽水域に生息する。受精囊瓶状部の壁は 薄く, 内部の精子は束, または塊状となる。受精囊は基本 的には食道に接続するが, 内管は食道と繋がらない.アミ メヒメミミズ属 Chamaedrilusに似るが, 本属では精囊が あまり発達しない点や受精囊が食道に接続する点などから 区別できる。これまでミズヒメミミズ Marionina riparia と されてきた種は, Christensen \& Dòzsa-Farkas（2012）によ り Globulidrilus に移され, G. riparius (Bretscher) となっ た. 日本からは, 河川の中下流域の岸際, 汽水域などから ミズヒメミミズ G. riparius が確認され, Torii（2015）に より尾瀬ヶ原からキタヒメミミズ Globulidrilus helgei Christensen \& Dòzsa-Farkas が確認されている.

ホソヒメミミズ属（和名新称） Grania Southern, 1913

主に海域から汽水域に生息する。剛毛は 1 束 1 本で強大 で頑丈. 受精囊瓶状部中の精子束はリング状となる. 精囊 や卵囊は長く後方まで伸びる。

本属は背側および腹側に各 1 本の大きく頑丈で真っ直ぐ かつ尖った剛毛があることから, 他の海棲種から容易に区 別される，ただし剛毛が全く無い種も存在する．体壁には 付着物がなく，表皮が厚いため，やや硬い感じがする。そ のため動きも硬く，一見すると線虫の様にもみえる．種の 判別には剛毛の形や配置, 受精囊, 雄生生殖器の形や構造 が重要である.成熟していなければ種の判別はできない （DNAによる種判別であれば可能な場合もある）. 雄性生 殖器は複雑な構造をしており, いくつかの種では雄性孔付 近にクチクラ質の penial stylet と呼ばれる構造物が付随す る（Erseus \& Lasserre 1976）。これまで日本から本属の記 録はなかったが, 日本各地の海底砂礫中, 河口の汽水域な どから本属に含まれる複数種が確認されている（鳥居未 発表).

属和名無し Guaranidrilus Černosvitov, 1937

日本から本属の記録はない. 剛毛は真っ直ぐで結節はな く, 1 束に 2 本ある. 頭孔は 0 体節先端にある. 背孔はな い. 食道と腸は急に繋がる. 腸の憩室が食道と腸の接続部 に 1 対ある. 食道㕷室が第 6 体節に 1 対ある. 背血管は環 帯の前か環帯の中から始まる、受精囊はある。陰茎球はコ
ンパクトである。受精囊は単純で食道に繋がらない (Nielsen \& Christensen 1959; Healy 1979).

ハンヒメミミズ属 Hemienchytraeus Černosvitov, 1934

剛毛は真っ直ぐで結節はなく，1束に 2 本ある. 咽頭の

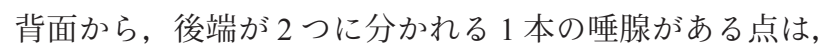
ヒメミミズ科の中でも本属のみが有する特徴である. 食道 や腸には憩室が無い。隔膜前の腎管は広がった腎口をもつ (Coates \& Ellis 1981). 日本からはフタオレハンヒメミミ ズ Hemienchytraeus bifurcatus Nielsen \& Christensen, ミツオ レハンヒメミミズ Hemienchytraeus stephensoni (Cognetti) の 2 種が本州の芝生土壌中から記録されている（中村 1999).ただし Schmelz \& Römbke（2005）は，上記 2 種に 対する種の定義が不明確であり，これまでのこれら 2 種の 記録には複数種が含まれる可能性を指摘している.

属和名無し Hemifridericia Nielsen \& Christensen, 1959

日本から本属の記録はない。比較的小型の種が多い. 剛 毛は真っ直ぐで結節はなく，基部は曲がる．頭孔は $0 / 1$ に ある. 主咽頭腺は第 4 体節から第 6 体節にあり, 二次咽頭 腺はない. 食道㕰室は多くの場合ない. 背血管は第 12 体 節〜第 13 体節から始まる. 色素のない 2 種類の体腔細胞 （粘液細胞とレンズ状細胞）が存在する. 受精囊孔付近に 腺組織はなく, 受精囊瓶状部に咊室はない（Schmelz \& Collado 2010).

\section{コブヒメミミズ属 Henlea Michaelsen, 1889}

真っ直ぐか, 多少曲がった剛毛を持ち，1束の中で長さ が異なっており，外側のものほど長くなる．食道は急激に 広がり腸に繋がる．食道憩室が第 4 体節から第 6 体節の間 に背中側と腹側に 1 対ずつある。一部の種では唾腺に似た 食道付属器が，第 4 体節から第 6 体節にかけて存在する場 合がある．腸には揗室がある場合とない場合がある．背血 管は普通，第 8 か第 9 体節から始まる．腎管の排出管は前 方から始まる（Coates \& Ellis 1981）。日本からは北海道お よび四国の森林土壤中から，ヒナコブヒメミミズ Henlea perpusilla Friend およびマルコブヒメミミズ Henlea ventriculosa (d'Udekem) の 2 種が記録されている（Nakamura \& Christensen 1978; 中村 1999). 本州でも本属は, 渓流脇の 滴りの溜まりや湿った森林土㙵中から普通に確認される が, 種の確定には至っていない（鳥居未発表）.

\section{ツリヒメミミズ属 Lumbricillus Ørsted, 1844}

とてもよく発達した精囊を持つ. 受精囊孔や受精囊導管 に沿って腺組織が存在する。咽頭や食道に付属器や憩室は 無い. 剛毛には結節がなく多くの場合 S 字状となり, 1 剛 毛束あたり 2 本以上となる。受精囊孔の周辺には腺組織が 存在する。種の判別には受精囊の僅かな形, サイズ, 付属 腺の付き方などの特徵が有効である. 雄性孔につく陰茥球 
は小さい. 脳神経節の後方は切れ込む（Coates \& Ellis 1981). Marionina（ミズヒメミミズ属）との区別が難しい が, Nielsen \& Christensen（1959）によると, 本属はとても よく発達した小胞状の精囊を持つことや, 腎管の排出管の 出る位置が本属では体節末端から，ミズヒメミミズ属では 体節中央よりから出るという違いによって区別可能として いる。しかし，腎管の排出管の出る位置については，両属 共に後方から排出管が出る場合があり，明瞭な区別点とは ならない. 日本からは，河川の岸際などの湿潤環境からッ ヤヒメミミズ Lumbricillus lineatus (O. F. Müller), 海岸の波 打ち際などからイソヒメミミズ Lumbricillus nipponicus (Yamaguchi), 同様の環境から Lumbricillus annulatus Eisen が記録されている（中村 1999）。Lumbricillus nipponicusに 関しては, Coates \& Ellis（1981）は Lumbricillus annulatus との区別点が曖昧であることを指摘している.

ミズヒメミミズ属Ｍarionina Michaelsen, 1890

多くの異質な特徴を含む属であり, 本属に対する分類学 的定義は混乱している. 例外的な種はいるものの, 基本的 に血液には色が付いていないため, 生体時は白, または透 明である。受精囊は有る場合と無い場合がある。ほぼ全て の種が 7-8 mm より小さい. 剛毛を全く欠くか, 真っ直ぐ か $\mathrm{S}$ 字状の剛毛を持つ場合もあり, 1 束の剛毛の本数も 様久. 1 剛毛束あたり 0 数本程度である. 受精囊孔や受 精囊導管に沿って腺組織が存在する場合がある. 受精囊瓶 状部は時にはっきりと悡室状となり, リング状の精子束が みえることがある，脳神経節は後方で切れ込む場合と突出 する場合がある．腎管は隔膜前方に伸びる．背血管の前方 分岐は脳神経節や咽頭の後方で分かれる「ミズヒメミミズ タイプ」と, 脳神経節の前方で分かれる「ツヤヒメミミズ タイプ」の 2 タイプの存在が確認されている（Coates \& Ellis 1981). Healy（1994）は, Marionina は次の特徵によっ て区別できるとしている. サイズが小さく，その他のヒメ ミミズ科の属を定義する特徵を持たない. 例えば, 食道憩 室を持たない，腸に㮩室を持たない，前方起源の背血管を 持たない， 2 種類の体腔細胞をもたない，小胞状の精囊を もたない, 根元が広がるような剛毛をもたない, などの特 徵が挙げられる.すなわち, 小さなヒメミミズ科で他の属 に該当しないのであれば Marionina とされることが多い.

現在のところ 70 種以上から構成されているが, 多系統 群であることは間違いない. 近年, ミズヒメミミズ M. riparia とされてきた種は, Christensen \& Dòzsa-Farkas（2012） により Globulidrilus に移され，G. riparius (Bretscher) とさ れた。

日本からは, 琵琶湖からビワヒメミミズ M. biwaensis Torii およびスベスベヒメミミズ M. nevisensis Righi \& Kanner, 河川河口の汽水域からコーテスヒメミミズ M. coatesae Erséusの 3 種が記録されている（Torii 2011a）.
ナカヒメミミズ属 Mesenchytraeus Eisen, 1878

口前葉の先端に淡く黒い色素を持つ種が多いがその限り ではない，背側及び腹側の剛毛の数はしばしばかなり異 なっており, 腹側のほうが多い傾向にある. 表皮の腺細胞 は体前部でよく発達する。卵囊は存在し, しばしば体後部 （第 20 体節程度）にまで存在する. 頭孔は頭部先端に存在 する. 背孔はない. 剛毛は $\mathrm{S}$ 字状となり結節を持つ. 食 道と腸は徐々につながる. 体腔細胞は 1 種類のみから構成 される．腎管は体腔細胞が少ないためにはっきり見えるこ とが多い。腎管の後方は背中側が大きく, 腹側が小さい形 で分葉している．背血管は第 13 体節か, 環帯より後ろか ら始まる。生息場所は湿潤な場所（湿地等）が多い (Nielsen \& Christensen 1959). 日本からも本属の記録はあ るが, 詳細はほとんど未研究. 近年, Torii (2015) により ユキヒメミミズ M. nivalis が尾瀬ヶ原湿原から記載され た. 南極に生息し, コオリミミズやアイスワームなどの名 前で知られているM. solifugus Emery, 1898 は本属の一種で ある。

属和名無し Oconnorella Rota, 1995

日本から本属の記録はない. Rota（1995）により次に挙 げる共有派生形質により Marionina から分けられた属であ る. 剛毛は直線的で多少曲がる場合もあり結節はない. 剛 毛束は 2 本以上から成る. 3 本以上ある場合は真中の剛毛 ほど短くなる．背孔はなく, 頭孔が第 0 体節と第 1 体節の 間に位置する。食道と腸は滑らかに繋がる。一部の種では 唾腺に似た食道㕰室が，第 4 体節から第 6 体節にかけてあ る場合や第 7 体節に食道稳室が 1 対ある場合がある。腎管 にははっきりとした漏斗部があり，隔膜前方は漏斗部のみ から成る. Marionina との違いは，本属では隔膜前の腎管 が漏斗部のみから成ることである。腎管の排出管は腎管の 前方または中程から出る．背血管は環体の中か環体後方か ら始まる。体腔細胞は 1 種類からなる。受精囊はある場合 と無い場合がある. 雄性孔につく陰茎球は小さい，受精囊 瓶状部は単純か, 㕰室を持つ（Chen et al. 2006）.

属和名無し Pelmatodrilus Moore, 1943 検索表に含めず

日本から本属の記録はない，全体的に背腹方向に扁平な 形態である. 剛毛はわずかに S 字状で結節はなく先端は スプーン状を呈する．食道と腸は滑らかに繋がる，背血管 は第 7,8 体節から始まる. 受精囊孔に大きな腺組織が付 属するが受精囊自体は単純で, 食道に繋がる. Aspidodorilus と同様に大型の陸棲貧毛類の体表面に寄生し，体表面 の分泌物に付着する土壌粒子やバクテリア，有機物等を摂 食すると考えられる (Coates 1990)，日本から本属の記録 はない. ジャマイカの高山から記録されている（Moor 1943）。

属和名無し Randidrilus Coates \& Erséus, 1985

日本から本属の記録はない，海や汽水に生息する．腹側 
の両側面には第 2 体節から 1 本ずつ剛毛を持つ. 受精囊は 1, 2 対有る. 雄性孔の前後には多くの細かな腺組織が存 在する.Graniaに似るが, 区別点として受精囊孔に腺組 織が付属することが挙げられる（Locke＆Coates 2000）.

属和名無し Sinenchytraeus Liang et Hsu, 1979 検索表に含 めず

日本から本属の記録はない，チベットの氷河に生息する 1 種が知られる. Mesenchytraeus と同様に剛毛は S 字状と なり結節を持つ. 食道と腸は徐々につながる. 頭孔は頭部 先端にある. 背孔はない. 4 対の咽頭腺を持つ. 体腔細胞 は 1 種類のみから構成される. 受精囊はない. Mesenchytraeus と比較して, 腎管に間隙がない点や, 精囊に包まれ た大きな精巣を持つ点, 咽頭腺の数が多い点, 受精囊を持 たない点などの特徵により区別される（Liang et al. 1979）.

\section{ウミヒメミミズ属Ｓtephensoniella Černosvitov, 1934}

主に海域や汽水域に生息する。僅かに S 字状となった 剛毛は 1 束に 2,3 本ある. 雄性孔につく陰茎球は小さい. 受精囊瓶状部は球形か囊胞状である. 第 5 体節と第 6 体節 の間と第 8 体節と第 9 体節の間の隔膜は肥厚する. 食道と 腸は緩やかに繋がる. 背孔はない. 受精囊はほとんどの場 合，腸に接続するが，実際には繋がっていない場合もある (Coates \& Ellis 1981; Coates 1983). ツリヒメミミズ属 Lumbricillus やミズヒメミミズ属 Marionina に近い属であ るが, 精囊が小胞状にならない（unlobed form）ことや, 剛毛の位置や形, 受精囊瓶状部に一つの丸みを帯びた㕰室 があることから区別できる，また，ヒメミミズ属 Enchytraeus からは陰茎球が小さい点や, 食道䰅室が無い点など の特徵により区別される.

沖縄県の海域（海岸や河川が流入する湾内）の砂礫中か らウミヒメミミズ Stephensoniella marina (Moore) とコガ タウミヒメミミズ Stephensoniella sterreri (Lasserre \& Erséus）の 2 種が記録されている（鳥居 2013）。

\section{ミユキヒメミミズ属Ｓtercutus Michaelsen, 1888}

剛毛は $\mathrm{S}$ 字状となるが結節がなく, 頭孔, 背孔ともに ない. 前方の腹側剛毛は通常の 2 倍程度の太さになること がある．食道と腸は緩やかに慗がる．食道や腸に悡室がな い. 背血管は環帯よりも前から始まる. 雄性漏斗は小さ い. 受精囊は単純で㮩室はなく, 食道に繋がらない.この 属は系統的な位置がはっきりしていない（Nielsen \& Christensen 1959). 日本からはミユキヒメミミズ Stercutus niveus Michaelsen の 1 種が北海道の畑土袞中から記録されている （中村 1999）。酸性土壌からはほとんどみられない。

\section{属和名無し Timmodrilus Dozsa-Farkas, 1997}

日本から本属の記録はない。背孔がないという特徵以 外, すべて Fridericia と同様の特徵を持つ属である.
Schmelz（2003）は Fridericiaのシノニムの可能性を指摘 している.

属和名無し Xetadrilus Schmelz, Collado \& Römbke, 2011

日本から本属の記録はない, 体長は $2-5 \mathrm{~mm}$ 程度, 体幅 は 0.1-0.2 mm 程度の小さなミミズである. 剛毛はほぼ まっすぐで基部が傘の柄の様に曲がる. 背側剛毛は第 8 体 節前後から後方で全く欠き, 腹側剛毛は 1 剛毛束に 2 本ず つ存在する. 頭孔は口前葉の背面に開く. 表皮の腺細胞は 楕円形、口前葉内部前方にくぼみが存在する。口前葉内 部に乳頭状突起がある.脳の前方部に神経塊がある。脳は 長細く, 後方は切れ込む. 食道に鄎室はない. 腸はしばし ば第 6 体節と第 7 体節の間から拡張する. 背血管は環帯中 もしくは環帯後方から始まる. 体腔細胞は 1 タイプのみ存 在する. 受精囊孔には腺細胞は付随せず, 受精囊は食道に 慗がらない（Schmelz et al. 2011）。Guaranidrilusに似るが, 背側剛毛は第 8 体節前後から後方にかけて全く欠く点など の特徴により区別される。ブラジルから 3 種が記載されて いる.

謝 辞: 本原稿をまとめるにあたり, 大高明史教授（弘前大学 教）には本分類群の研究を始めるきっかけを与えていただくとと もに本原稿に対する多くの有益な情報やご助言等を受けた。ま た, Rüdiger M. Schmelz 博士（ECT Oekotoxikologie GmbH, Germany, and Universidad de A Coruña, Fac. Ciencias, Spain)，にはヒメミ ミズ科の分類の基礎をご教授いただくとともに本原稿の abstract に対する助言を受けた。記して感謝します。

\section{引用文献}

Beylich, A. and R. K. Achazi 1999. Influence of low soil moisture on enchytraeids. Newsletter on Enchytraeidae, 6: 49-58.

Chen, J., Z. Xie, Z. and S. He 2006. A taxonomic study of Oconnorella (Enchytraeidae, Oligochaeta) from Changbaishan Mountain. China. Zoological Science, 23(10): 917-922.

Christensen, B. and K. Dózsa-Farkas 2012. A new genus Globulidrilus and three new enchytraeid species (Oligochaeta: Enchytraeidae) from Seoraksan National Park (Korea). Journal of Natural History, 46 (45-46): 2769-1785.

Coates, K. A. and D. V. Ellis 1981. Taxonomy and distribution of marine Enchytraeidae (Oligochaeta) in British Columbia. Canadian Journal of Zoology, 59(11): 2129-2150.

Coates, K. A. 1983. A contribution to the taxonomy of the Enchytraeidae (Oligochaeta). Review of Stephensoniella, with new species records. Proceedings of the Biological Society of Washington, 96 (3): 411-419.

Coates, K. A. 1990. Redescriptions of Aspidodrilus and Pelmatodrilus, enchytraeids (Annelida Oligochaete) ectocommensal on earthworms. Canadian Journal of Zoology, 68 (3): 498-505.

Collado, R., E. Hass-Cordes and R. M. Schmelz 2012. Microtaxonomy of fragmenting Enchytraeus species using molecular markers, with a comment on species complexes in enchytraeids. Turkish Journal of Zoology, 36: 85-94.

Dial, C. R., R. J. Dial, R. Saunders, S. A. Lang, B. Lee, P. Wimberger, M. S. Dinapoli, A. S. Egiazarov, S. L. Gipple, M. R. Maghirang, D. J. Swartley-McArdle, S. R. Yudkovitz, and D. H. Shain, 2012. Historical biogeography of the North American glacier ice worm, Mesenchytrae- 
us solifugus (Annelida: Oligochaeta: Enchytraeidae). Molecular Phylogenetics and Evolution, 63: 577-584.

Erseus, C. and P. Lasserre 1976. Taxonomic Status and Geographic Variation of the Marine Enchytraeid genus Grania Southern (Oligochaeta). Zoologica Scripta, 5: 121-132.

Erséus, C., E. Rota, L. Matamoros and D. W. Pierre 2010. Molecular phylogeny of Enchytraeidae (Annelida, Clitellata). Molecular Phylogenetics and Evolution, 57: 849-858.

Healy, B. 1979. Review of the genus Guaranidrilus (Oligochaeta, Enchytraeidae) with the description of two new species. Journal Bulletin of the British Museum (Natural History) Zoology, 37: 7-15.

Healy, B. 1996. Records of Enchytraeidae (Annelida: Oligochaeta) from west Florida. 1. Mesenchytraeus, Cognettia, Bryodrilus, Hemienchytraeus, Henlea and Buchholzia. Proceedings of the Biological Society of Washington, 109(1): 118-137.

Healy, B. 1994. New species of Marionina (Annelida: Oligochaeta: Enchytraeidae) from Spartina Salt Marshes on Sapelo Island, Georgia, U.S.A. Proceedings of the Biological Society of Washington, 107(1): 164-173.

Kasprzak, K. 1986. Skąposzczety Wodne i Glebowe, II. Rodzina: Wazonkowce. Water and Soil Oligochaeta, II. Family: Enchytraeidae. PWN, Warszawa.

Liang, Y. L., C. F. Hsü and T. N. Chang 1979. A new genus and species of Enchytraeidae from Tibet. Acta Zootaxon Sinica, 4: 312-317.

Locke, J. M. and K. A. Coates 2000. An illustrated key to the species of Grania and Randidrilus (Annelida: Clitellata: Enchytraeidae) of eastern North America, Bermunda, and the Caribbean area. Proceedings of the Biological Society of Washington, 113(3): 617-632.

Martinsson, S., E. Rota and C. Erséus 2014. Revision of Cognettia (Clitellata, Enchytraeidae): re-establishment of Chamaedrilus and description of cryptic species in the sphagnetorum complex. Systematics and Biodiversity, 13 (3): 257-277.

Moore, J. P. 1943. Pelmatodrilus planariformis, a new oligochaete (Enchytraeidae) modified for epizootic life on. Jamaican earthworms. Notulae Naturae of the Academy of. Natural Sciences of Philadelphia, 128: $1-7$.

Murakami, T., T. Segawa, D. Bodington, R. Dial, N. Takeuchi, S. Koshima and Y. Hongoh 2015. Census of bacterial microbiota associated with the glacier ice worm Mesenchytraeus solifugus. FEMS microbiology ecology, 91: 1-10.

Myohara, M., C. Yoshida-Noro, F. Kobari, and S. Tochinai 1999. Fragmenting oligochaete Enchytraeus japonensis: A new material for regeneration study. Development Growth and Differentiation, 41: 549-555.

中村好男 1999. ミミズ綱 (貧毛綱). 日本産土壌動物（青木淳一 編), 東海大学出版会, 神奈川, pp. 103-110.

Nakamura, Y. and B. Christensen 1978. Enchytraeids in Japan (1). Bulletin of the National Grassland Research Institute, 12: 32-37.

中村好男 2000 . ヒメミミズ類の種の目録. 東北農業試験場研究資 料, $24: 29-104$.

Nielsen, C. O. and B. Cristensen 1959. The Enchytraeidae: critical revision and Taxonomy of European Species. Natura Jutlandica, 8-9: $1-160$.

Römbke, J., S. Jänsch, H. Höfer, F. Horak, M. Roß-Nickoll, D. J. Russell and A. Toschki 2013. State of knowledge of enchytraeid communities in German soils as a basis for biological soil quality assessment. Soil Organisms, 85: 123-146.

Rota, E. and C. Erséus 2003. New records of Grania (Clitellata, Enchytraeidae) in the Northeast Atlantic (from Tromsö to the Canary Islands), with descriptions of seven new species. Sarsia, 88(3): 210-
243.

Schmelz, R. M. 2003. Taxonomy of Fridericia (Oligochaeta, Enchytraeidae): Revision of species with morphological and biochemical methods. Abhandlungen des naturwissenschaftlichen Vereins in Hamburg (Neue Folge), Otto K. (ed.), 38. 415 pp +73 full-page figures.

Schmelz, R. M. and J. Römbke 2005. Three new species of Hemienchytraeus (Enchytraeidae, Oligochaeta) from Amazonian forest soil. Journal of Natural History, 39: 2967-2986.

Schmelz, R. M. and R. Collado 2010. A guide to European terrestrial and freshwater species of Enchytraeidae (Oligochaeta). Soil Organisms, 82(1): 1-176.

Schmelz, R. M., R. Collado and J. Römbke 2011. Mata Atlântica enchytraeids (Enchytraeidae, Oligochaeta): Description of a new genus, Xetadrilus gen. nov. with three new species, and four new species of Guaranidrilus Černosvitov. Zootaxa, 2838: 1-29.

Schmelz, R. M. and R. Collado 2012a. Guide to European Terrestrial and Freshwater Species of Enchytraeidae (Oligochaeta): First supplement. In Schrader, S. and R. M. Schmelz (eds.), Newsletter on Enchytraeidae No. 12. Proceedings of the ninth international symposium on Enchytraeidae, 14-16 July 2010, Braunschweig, Germany. Landbauforschung vTI Agriculture and Forestry Research, Special Issue 357: pp. 53-66.

Schmelz, R. M., and R. Collado 2012b. An updated checklist of currently accepted species of Enchytraeidae (Oligochaeta, Annelida). In Schrader, S. and R. M. Schmelz (eds.), Newsletter on Enchytraeidae 12. Proceedings of the ninth international symposium on Enchytraeidae, 14-16 July 2010, Braunschweig, Germany. Landbauforschung vTI Agriculture and Forestry Research. Special Issue 357: pp. 67-87.

Schmelz, R. M., and R. Collado 2013. Enchytraeidae (Oligochaeta, Annelida) from a field site in Portugal, with the description of five new species and a redescription of Enchylea heteroducta Nielsen and Christensen, 1963. Zootaxa, 3647(2): 307-328.

Schmelz, R. M., M. Jocque and R. Collado 2015. Microdrile Oligochaeta in bromeliad pools of a Honduran cloud forest. Zootaxa, 3947(4): 508-526.

Torii, T. 2006. New Record of Propappus volki (Annelida: Clitellata: Propappidae) from Japan. Species Diversity, 11: 359-365.

Torii, T. 2011a. New Records of semi-aquatic species of Marionina (Clitellata, Enchytraeidae) from Japan, with a description of Marionina biwaensis sp. nov. Turkish Journal of Zoology, 35 (3): 1-10.

Torii, T. 2011b. New record of Cernosvitoviella minor (Annelida: Clitellata: Enchytraeidae) from hyporheic habitat in a Japanese stream. Edaphologia, 88: 31-35.

鳥居高明 2012. 尾瀬ヶ原湿原のヒメミミズ科（環形動物門環帯 綱). 低温科学, 70: 93-98.

鳥居高明 2013. 沖縄県から採集された日本初記録となるウミヒメ ミミズ属 (新称) Stephensoniella Černosvitov, 1934 (環形動物門 : 環帯綱：イトミミズ目：ヒメミミズ科)の 2 種. Fauna Ryukyuana, 6: 1-6.

Torii, T. 2015. Descriptions of two new and one newly recorded enchytraeid species (Clitellata, Enchytraeidae) from the Ozegahara Mire, a heavy snowfall highmoor in Central Japan. Zootaxa, 4000(4): 473482.

Tosza, E., E. Dumnicka, M. Niklińska and A. Rożen 2010. Enchytraeid and earthworm communities along a pollution gradient near Olkusz (southern Poland). European Journal of Soil Biology, 46: 218-224.

Zhicai, X., L. Yanling and W. Hongzhu 2000. Taxonomic Study of Bryodrilus (Enchytraeidae, Oligochaeta) from Changbaishan Mountain, China. Species Diversity, 5: 93-101. 